Article

\title{
Economic Impact of the Health Insurance System on Slovak Medical Spas and Mineral Spring Spas
}

\author{
Ján Derco ${ }^{1, * \mathbb{C}}$, Piotr Romaniuk ${ }^{2} \mathbb{D}$ and Michal Cehlár ${ }^{3}[\mathbb{C}$ \\ 1 Faculty of Mining, Ecology, Process Control and Geotechnologies, Technical University of Kosice, \\ Nemcovej 32, 04200 Kosice, Slovakia \\ 2 Department of Health Policy, School of Health Sciences in Bytom, Medical University of Silesia in Katowice, \\ Ul. Piekarska 18, 41-902 Bytom, Poland; promaniuk@sum.edu.pl \\ 3 Faculty of Mining, Ecology, Process Control and Geotechnologies, Technical University of Kosice, Letna 9, \\ 04200 Kosice, Slovakia; michal.cehlar@tuke.sk \\ * Correspondence: jan.derco@tuke.sk; Tel.: +421-055-602-2443
}

Received: 15 March 2020; Accepted: 18 April 2020; Published: 21 April 2020

check for updates

\begin{abstract}
The article deals with the financing of spa undertakings through the health insurance system. The analysis is based on the financial statements of 28 spa undertakings operating in the Slovak Republic, their contracts with the individual health insurance companies and secondary data sources (accommodation statistics of these undertakings, the number of medical stays paid by clients themselves and of those covered by public health insurance, the spa treatment expenditure of the health insurance companies, the percentage of this expenditure out of the total expenditure spent by the health insurance companies on health care). The still significant percentage of revenues from the health insurance companies out of the total revenues of spa undertakings shows the prevalence of the medical nature of spa care. At the same time, it reflects the current tax measures related to the spa industry and shows that the introduction of a recreation allowance might influence the future development of spa care.
\end{abstract}

Keywords: health insurance; health tourism; medical spas; spa tourism; state support

\section{Introduction}

In the 20th century, the ownership of spa undertakings and the manner of financing spa care changed twice in the Slovak Republic. The first fundamental social and economic changes occurred after World War II. It has been noted that "these changes radically changed the quantitative and qualitative parameters of Slovak spas. The traditional picture of spa life as a leisure time and a way of social and cultural enjoyment was ideologically unacceptable for communists. With the rise of state centralization, regulated economy and state-owned health and social services, a significant reduction of the spa network took place" [1]. Act No. 125/1948 on the nationalization of natural healing springs and on the incorporation and management of confiscated property of 1948 was crucial for the fate of Slovak spas. Thus, the State acquired the exclusive right to dispose of the healing springs and the title to the property of the spas. The Act was also the first step towards the inclusion of the spa industry in a unified health system, excluding its economic use and inbound tourism [2]. Finally, the nationalization process resulted in all spa facilities being run by the single operator- the Czechoslovak State Spas [3]. Notably, "after the nationalization of spas and springs in 1948, the ratio between patients sent for treatment by the national insurance company and private spa guests (self-payers) began to change significantly. In 1948, policyholders (state-insured patients) accounted for only about $15 \%$ of all spa guests. In 1953, the ratio was already reversed-85\% accounted for policyholders and only $15 \%$ for private spa guests-self-payers. In 1954, only 244 domestic and 53 foreign clients received treatment at 
the spas managed by the Main Administration of Specialized Medical Institutes, Spas and Springs at their own expense. Although the number of beds reserved for self-payers had been growing since 1955 , the percentage of spa clients who paid for their stays themselves was less than $2 \%$. In these early years, the importance of spas as recreation and tourism centers was underestimated. New construction began in the 1960s of the 20th century, but not everywhere and not at the same time" [4].

The second significant change of the Slovak spas was their economic transformation during the changed political and social conditions that developed after 1990. According to the original plans, the restructuring of the state-owned Slovak medical spas was intended to create 14 joint-stock companies with $51 \%$ state participation, $5 \%$ was earmarked for voucher privatization, $5 \%$ intended for the municipalities in whose territories the spas were located, $3 \%$ for restitutions and $36 \%$ for public auction [5]. As the spa industry was considered to be one of the most lucrative and promising economic sectors within the Slovak economy, there was a lot of interest in its privatization. As a result, the original privatization plan was changed [6]. The municipal shareholdings rose to $10 \%$ and the shareholding intended to be sold within a public tender was increased to $51 \%$. On the other hand, the shareholding allocated to the National Property Fund of the Slovak Republic decreased to $20-34 \%$ (state-owned shareholdings) [5]. The privatization of the spa undertakings was expected to help restore dilapidated buildings, improve services, invest in the renewal of healing springs and bring an influx of foreign clients [6]. For most of the spas, this process took place in the period of 1995-1997 [1]. The way the privatization was carried out [7] was questioned and criticized by the public. Responses to this criticism led to the transformation of the state-owned undertakings into newly formed joint-stock companies whose statutes guaranteed the preservation of the medical character of the spas. For this purpose, the state-owned General Health Insurance Company (V̌̌eobecná zdravotná poist'ovňa) retained minority shareholdings in the spa undertakings. The privatization of the Slovak medical spas was accompanied by legislative reforms affecting the Slovak spa industry and spa care [6].

The other changes that affected spa care were (1) the emergence of the health insurance market in the early 1990s and (2) the changeover in the spa care financing from the state to the health insurance companies in 2004. The health insurance system started to operate based on Act No. 7/1993 Coll. on the establishment of the National Insurance Company and on the financing of health, sickness and pension insurance. The Act led to the establishment of a single insurance company on 1 January 1993, which was the holder of compulsory health, sickness and pension insurance. The incompatibility of all three systems led to problems. The lack of finances in the health sector was, inter alia, caused by the fact that the state was not able to fully comply with its obligations to pay insurance for a large economically passive/inactive population. This subsequently created a problem of insufficient financing of health care. Due to these and other reasons, the National Insurance Company ceased to exist, and both the Social Insurance Agency responsible for the sickness and pension insurance system and the state-owned health insurance company (V̌̌eobecná zdravotná poist'ovňa) were established on 1 January 1995. Pursuant to Section 49 of Act No. 274/1994 Coll. on the Social Insurance Agency, spa care was covered by a special Social Insurance Agency account into which money was paid by the state. Under Act No. 273/1994 Coll., private health insurance companies could also be established from 1 January 1995. The health insurance market has stabilized gradually; there is currently only one state-owned health insurance company (Všeobecná zdravotná poist'ovňa), and there are two private health insurance companies (Dôvera and Union) [6,8]. The Social Insurance Agency significantly reduced the purchase of 'spa vouchers' and the expenditures related to spa care. Therefore, the responsibility to pay for spa care was transferred from the Social Insurance Agency to the health insurance companies in 2004.

"Natural Curative Spas are medical facilities where healthcare is provided to stabilise the state of health, regeneration of health or prevention of diseases and which use natural healing water or weather conditions suitable for treating recognised under Act 538/2005 Coll. to provide health care" [9]. "Spa care indicated for health reasons is fully (category A) or partially (category B) covered by public health insurance. The indications and length of medical stays (21-28 days) are set forth in Act No. 577/2004 on the Scope of Health Care Covered by Public Health Insurance and on Payments 
for Services related to the Provision of Health Care" [10]. In the case of medical spa stays under Category A, the insurance companies reimburse the costs of accommodation, catering services and spa care. However, clients have the option to pay for a higher standard of these services. The clients only pay a statutorily prescribed charge ( $€ 1.70$ per night) and a local accommodation tax. In the case of indications of Category B, the insurance companies only reimburse the costs of health care (medical examination including diagnostic services, three treatment procedures per day on average and the administration of medicines in the case of acute diseases or deterioration of the state of health). Accommodation and catering services are chosen and paid by the clients themselves [11]. The financial stability of these undertakings is based on the balance between medical products covered by public health insurance and medical and wellness products reimbursed by patients [10]. Qualifying patient into Category A or B is dependent on the disease being treated, as specified in the Appendix 6 to Act No. 577/2004 on the Scope of Health Care Covered by Public Health Insurance and on Payments for Services related to the Provision of Health Care.

Regulation of prices related to spa care by health insurance companies does not take into account the needs of spa businesses but mainly the needs of insurance companies. In Slovakia [11-15], the Czech Republic [14,16] and Poland [17-23], spa therapy is an integral part of the public health system, but medical facilities providing these services also act as tourist establishments. The uncertainty of financing products with strong medical backgrounds have forced businesses to look for new products to be offered in this sector, the financing of which would not be bound only to public finances. Short stays marketed as wellness, medical wellness or relaxation include activities aimed at improving mental and physical conditions, as these treatments are not specifically used for the treatment of concrete diseases. Its funding is not regulated and prices reflect actual costs [9].

Smith and Puczkó [24] described regional and cultural differences in understandings of European health and wellness tourism in Northern, Western, Southern, Central and Eastern Europe. It is difficult to compare medical services provided in the Slovak spas with those of other destinations [25-35]. This is due to the different legislative framework in each country. There is also variance in the level of social or health care coverage. The issues of the spas' orientation towards the target clientele according to the analyzed forms of reimbursement, the dependence of their financing on the health insurance system and the percentage of such financing (plus other factors mentioned in this article) are crucial in any legislative changes and discussion about them. An example of this is the crisis situation in the Czech Republic in 2013 after the adoption of a restrictive indication list, which shortened the length of spa stays for certain diagnoses, reduced re-stays, introduced regulatory fees and canceled the reimbursement of stay costs for certain diagnoses from public health insurance [32,35]. The current legislative framework for this kind of business imposes strict requirements not only on the material and technical equipment and staff of natural medical spas, but also on the use and protection of natural healing springs, their monitoring, recognition of climatic conditions suitable for treatment and their protection, the protection of the spa area and spa environment requirements. Meeting these criteria requires resources to cover costs which are not expended by hotels focused solely on the wellness segment. This aspect should be taken into account when assessing the competitiveness of spa facilities and non-medical facilities. At the same time, however, the issue of financing these undertakings is important not only for the undertakings themselves and for the local economy built on the use of natural healing springs in spa facilities, but also in terms of the aforementioned environmental aspects and a sustainable spa care concept.

The aims of this article are:

1. to analyze the development and changes of financial conditions related to spa treatment in Slovakia in years 2006-2018. We also analyze the percentage of medical spa care expenditure compared to the total health care expenditure of the health insurance companies.

2. to determine the proportion/importance of the medical segment covered by public health insurance in relation to the segment of self-payers seeking wellness or medical wellness (care under medical supervision with the use of natural healing springs for balneotherapy). 
3. to analyze correlations between revenues of spas and after-tax profits of spas with the factors determining their infrastructural and financial environment.

\section{Materials and Methods}

Mainil et al. [36] states that "distinguishing the size of each of the markets in health tourism (i.e., medical, wellness and spa tourism) in the EU is difficult due to the limited and fragmented data available and the wide (and often overlapping) scope of the definitions used by different sources and statistical bureaus". This analysis is based on secondary data sources [37-51]. The data on the amount of financially recognized services paid out of public health insurance to natural medical spas and the percentage of this expenditure out of the total expenditure spent by the health insurance companies on health care are sourced from the Reports on the state of public health insurance for 2005-2018, as published by the Health Care Surveillance Authority [52-65]. The current amount of reimbursements is obtained from the contracts between the individual health insurance companies and the spa undertakings. The accommodation statistics contain data from Monthly Accommodation Facility Activities Reports to be submitted by the accommodation facilities to the Statistical Office of the Slovak Republic. The National Health Information Centre collects client data through Completed Spa Treatment Reports and the Annual Report on Natural Medical Spas.

The data on revenues (from the sale of services and goods) and after-tax profits of 28 natural medical spas operating in the Slovak Republic have been obtained from the public register of financial statements (http://www.registeruz.sk/cruzpublic/domain/accountingentity/simplesearch), which has been publishing the financial statements of companies since 2013. For the purpose of statistical analyses, we applied descriptive statistical methods as well as the Shapiro-Wilk test to verify the normality of distribution of data. Since non-normal distribution had been observed in most cases, the correlation analyses were performed using non-parametric methods, namely Spearman's correlation test [31] and Kendall's tau test. All statistical analyses were performed using Statistic aver. 13.3 software (TIBCO, Palo Alto, CA, USA).

\section{Results}

Table 1 provides basic information on the financing of medical spa treatment by public health insurance in Slovakia in the years 2006-2018, along with data on total revenues of the spa companies for the years 2013-2018 and their profits in the same period. From the presented data, we can observe that in 2006-2018, the amount of expenditure of insurance companies on medical spa treatment grew on a year-over-year basis, with the exception of the years 2012, where the amount was comparable to the previous year, and 2014, where a decrease appeared compared to 2013. The growth in nominal expenditure however did not directly translate into the increase of the share of spending on spa treatment in the total expenditure of health insurance companies. In the reporting period, this share accounted for $0.88-1.5 \%$ of total expenditure, presenting an upward trend up to 2011, but decreasing in the following years, despite general increase in nominal expenditure. The total revenues of spa companies in a given period generally showed a growing trend, while the share of income gained from insurance companies in their total revenues, after a decrease between 2013 and 2014, generally remained at a similar level, with some slight fluctuations between years. A similar situation tends to appear in terms of spa companies' profits, which do not show a clear trend, although losses only appeared once instead of profits, and profits generally appeared to be visibly higher in 2018 compared to in previous years.

To verify what the possible determinants of spa companies' financial results are, we decided to apply correlation tests comparing companies' revenues and profits with a set of factors potentially determining them. Results are presented in Table 2. 
Table 1. Services of spa undertakings financially recognized by the health insurance companies (EUR) and their percentage in the total health care expenditures of the health insurance companies in 2006-2018, revenues (from the sale of services and goods) and profits/losses of spa undertakings (EUR) in 2013-2018.

\begin{tabular}{|c|c|c|c|c|c|c|c|}
\hline & 2006 & 2007 & 2008 & 2009 & 2010 & 2011 & 2012 \\
\hline $\begin{array}{l}\text { Public health insurance expenditure on } \\
\text { medical spa treatment }\end{array}$ & $16,698,883$ & $25,546,905$ & $36,240,453$ & $42,156,543$ & $44,680,727$ & $49,241,510$ & $46,429,978$ \\
\hline \multirow{2}{*}{$\begin{array}{l}\text { Percentage of medical spa treatment } \\
\text { expenditure out of the total expenditure } \\
\text { of the health insurance companies }\end{array}$} & 0.88 & 1.04 & 1.23 & 1.31 & 1.35 & 1.50 & 1.38 \\
\hline & 2013 & 2014 & 2015 & 2016 & 2017 & 2018 & \\
\hline $\begin{array}{l}\text { Public health insurance expenditure on } \\
\text { medical spa treatment }\end{array}$ & $49,524,141$ & $47,867,905$ & $48,924,934$ & $52,365,195$ & $52,887,253$ & $56,112,848$ & \\
\hline $\begin{array}{l}\text { Percentage of medical spa treatment } \\
\text { expenditure out of the total expenditure } \\
\text { of the health insurance companies }\end{array}$ & 1.39 & 1.25 & 1.23 & 1.24 & 1.00 & 1.25 & \\
\hline $\begin{array}{l}\text { Revenues of spa undertakings in } \\
\text { 2013-2018 }\end{array}$ & $139,655,694$ & $146,578,286$ & $146,347,229$ & $156,236,005$ & $162,570,995$ & $169,661,551$ & \\
\hline $\begin{array}{l}\text { Percentage of reimbursements from the } \\
\text { health insurance companies in the } \\
\text { revenues of spa undertakings }\end{array}$ & 35.46 & 32.66 & 33.43 & 33.52 & 32.53 & 33.07 & \\
\hline $\begin{array}{l}\text { After-tax profits of spa undertakings in } \\
\qquad 2013-2018\end{array}$ & $4,866,307$ & $4,092,029$ & $5,830,157$ & $-2,403,112$ & $5,687,645$ & $6,114,908$ & \\
\hline
\end{tabular}

Source: [52-65], The data on revenues (from the sale of services and goods) and after-tax profits of spa undertakings have been obtained from the public register of financial statements (http://www.registeruz.sk/cruzpublic/domain/ accountingentity/simplesearch).

Table 2. Spearman's and Kendall's tests comparing companies' after-tax profits and revenues with a set of factors potentially determining them.

\begin{tabular}{|c|c|c|}
\hline Kendall's Tau & Profits & Revenues \\
\hline Numbers of beds & -0.333333 & -0.600000 \\
\hline Number of domestic visitors & 0.066667 & 0.600000 \\
\hline Number of which medical stays reimbursed by the insurance company & 0.066667 & 0.866667 \\
\hline Number of which medical stays reimbursed by the patient & 0.466667 & 0.733333 \\
\hline Number of nights spent at spa companies by domestic visitors & 0.200000 & 0.733333 \\
\hline Number of foreign visitors & -0.333333 & -0.333333 \\
\hline Number of medical stays reimbursed by the insurance company & -0.466667 & -0.200000 \\
\hline Number of medical stays reimbursed by the patient & -0.333333 & -0.333333 \\
\hline Number of nights spent at spa companies by foreign visitors & -0.333333 & -0.866667 \\
\hline Total number of visitors & 0.066667 & 0.600000 \\
\hline Total number of nights spent at spa companies & 0.066667 & 0.866667 \\
\hline Number of medical stays in spa facilities & 0.333333 & 0.600000 \\
\hline Public health insurance expenditure on medical spa treatment (EUR) & 0.333333 & 0.600000 \\
\hline Total healthcare expenditures financially recognized by the health insurance companies (EUR) & 0.333333 & 0.866667 \\
\hline $\begin{array}{l}\text { The percentage of medical spa care expenditure out of the total health care expenditure of the } \\
\text { health insurance companies }\end{array}$ & -0.200000 & -0.200000 \\
\hline Gross Domestic Product of Slovakia at current prices (nominal GDP) (Million EUR) & 0.333333 & 0.866667 \\
\hline Spearman's Test & Profits & Revenues \\
\hline Numbers of beds & -0.371429 & -0.657143 \\
\hline Number of domestic visitors & 0.028571 & 0.771429 \\
\hline Number of medical stays reimbursed by the insurance company & 0.142857 & 0.942857 \\
\hline Number of medical stays reimbursed by the patient & 0.542857 & 0.828571 \\
\hline Number of nights spent at spa companies by domestic visitors & 0.314286 & 0.885714 \\
\hline Number of foreign visitors & -0.600000 & -0.428571 \\
\hline Number of medical stays reimbursed by the insurance company & -0.657143 & -0.257143 \\
\hline Number of medical stays reimbursed by the patient & -0.485714 & -0.485714 \\
\hline Number of nights spent at spa companies by foreign visitors & -0.485714 & -0.942857 \\
\hline Total number of visitors & 0.028571 & 0.771429 \\
\hline Total number of nights spent at spa companies & 0.142857 & 0.942857 \\
\hline Number of medical stays in spa facilities & 0.428571 & 0.771429 \\
\hline Public health insurance expenditure on medical spa treatment (EUR) & 0.428571 & 0.771429 \\
\hline Total healthcare expenditure financially recognized by the health insurance companies (EUR) & 0.485714 & 0.942857 \\
\hline $\begin{array}{c}\text { The percentage of medical spa care expenditure out of the total health care expenditures of the } \\
\text { health insurance companies }\end{array}$ & -0.257143 & -0.257143 \\
\hline Gross Domestic Product of Slovakia at current prices (nominal GDP) (Million EUR) & 0.485714 & 0.942857 \\
\hline
\end{tabular}


Both Spearman's and Kendall's tests showed similar results, despite some slight differences in exact values of the correlation coefficient. We found that both revenues and profits are negatively and with a moderate or weak strength correlated with the global number of beds in spa companies, which may be interpreted as a symptom of the restructuring processes taking place in the companies and their efforts to optimize infrastructure. Similarly, a negative correlation appears in the case of the number of foreign visitors to spa companies operating in Slovakia. This correlation generally appears to be weak, although a stronger one has been shown by the Spearman's test in the case of after-tax profits. On the other hand, an interesting fact has been observed in relation to the general number of visitors and the number of domestic visitors to spa companies. In both cases a positive correlation exists, both with regard to revenues and profits. However, for revenues, this correlation is relatively strong and statistically significant when it comes to the numbers given in categories of reimbursed and self-paid stays, while in the case of profits, it appears to be positive but extremely weak. Interestingly, it is stronger, moderate in a general manner, although not statistically significant, for stays self-paid by patients. The dependence on public resources as a main source of income seems to be reflected by the correlation that appears in the case of total public expenditure on health care. Interestingly, this correlation is higher for general expenditure than for the part intended for spa treatment. Moreover, correlation with the factor showing the share of expenditure on spa treatment in general health expenditure appears to be negative and weak at the same time, while the value of the correlation coefficient with Slovak GDP takes the same values as in the case of correlation with general health expenditure.

\section{Discussion}

In our study, we observed several interesting facts regarding the operation of spa companies in Slovakia. Correlation analyses may lead to an interpretation that companies in general are becoming more dependent on domestic clients rather than on foreign ones, and that the revenues coming from public health insurance play a crucial and probably a growing role as their source of income. Profitability of the stays remains at a low level, being at the same time visibly higher in the case of self-paid patients. These observations seem to be confirmed by general data regarding development of the spa sector in Slovakia. In 2018, 28 Slovak natural medical spas operated 77 accommodation facilities. The total number of clients reached 311,963, of which 248,413 were domestic and 63,550 foreign clients. Out of this number, 72,702 domestic policyholders and 197 foreign policyholders received medical spa treatment paid for by a health insurance company. Another 73,128 domestic clients and 33,186 foreign clients received medical spa treatment paid by the patients themselves. Spa treatment is most often indicated for a group of musculoskeletal disorders-Vertebrogenic syndrome with transient painful spine disorders, post-traumatic conditions or conditions after musculoskeletal operations (mainly related to the following diagnoses: M40-M54 Spine and back diseases, M17 Gonarthrosis-arthrosis of the knee joint and M16 Coxarthrosis-arthrosis of the hip joint). The next most common reasons for treatment are non-tuberculous respiratory diseases and circulatory system diseases [66]. The remaining clients are accompanying persons (spouse of the client, mother with a child on medical stay, guide for the disabled) or guests who buy non-medical wellness products (such as weekend wellness stays including access to the aqua park, saunas or steam baths, but without a prescription for traditional balneological procedures provided by a specialist).

The rate of occupancy of permanent beds in the spa undertakings reached $66.3 \%$. The average number of overnights spent by domestic visitors was 9.4 and of those spent by foreign visitors was 7.2. When comparing these data with the data for 2005-2017 [10,37,38], it can be stated that: (1) an increase in the total number of clients occurred; (2) an increase in the number of medical stays of domestic clients covered by public health insurance (in 2018) or of those who paid themselves for their stays (in 2016-2018) occurred, (3) the number of foreign visitors has stabilized since 2009, (4) the traditional exploitation of natural healing springs for treatment, its connection to the public health insurance system and the level of spa treatments resulted in an increasing prevalence of medical stays (according 
to data on the total number of clients and the number of clients who received medical spa treatment). In 2006-2018, the amount of financially recognized services performed by spa undertakings grew on a year-over-year basis, with the exception of the years 2012 and 2014. In the reporting period, the percentage of this expenditure out of the total health care expenditure of the health insurance companies accounted for $0.88-1.5 \%$. A noteworthy fact is that the share of expenditure on spa services in the case of Slovak health insurance generally appears to be higher than for in neighbouring Poland, where after implementation of the health insurance in 1999, it remains at relatively stable level of circa $1 \%[67,68]$. Despite this fact, the Association of Slovak Spas proposes that the percentage of spa care expenditures be increased. This proposal seems to be well grounded in data regarding financial operation of spa companies, where the increase of stays and income not necessarily translates into better financial stability and profitability, as shown in our study, especially by the negative correlation between the share of spa treatment expenditure out of general health expenditure for health insurance. It is likely that the revenues and income of spa companies reflect the general condition of the Slovak economy, and thus its influence on health care financing, rather than any changes in policy of insurance companies regarding spa treatment. This observation is similar to that in Poland, where the expenditure are is perceived as being insufficient to sustain financial stability of the spa companies, despite the nominal increase in expenditure [69].

The share of reimbursements from the health insurance companies in 2013-2018 accounted for approximately one third of the revenues of spa undertakings. The losses reported in the spa sector in 2016 were due to the poor economic performance of one spa, which is currently being restructured. The impact of restrictive measures of the health insurance companies on the economy of the individual spa companies is mainly reflected in the amount of reimbursement provided by the health insurance companies per patient (treatment day). The amount of reimbursements by the health insurance companies per treatment day for indication group $A$ ranges between $€ 32.50$ and $€ 50.50$, and for indication group B it ranges between $€ 20.00$ and $€ 24.30$. The current situation is a natural consequence of the health insurance companies giving their preference to reimbursements for medicines, outpatient care and institutional care in hospitals. The solution is the currently adopted state support for accommodation facilities, including spa undertakings (in the segments of medical stays not covered by public health insurance, medical stays for indication group B, stays designated as medical wellness or wellness paid by self-payers), investments into the reconstruction and modernization of buildings, better promotion in the countries that are the main source markets (Czech Republic, Germany, Israel, Poland, Russia and Austria). For Europe, Directive 2011/24/EU on the application of patients' rights in cross-border healthcare regulates patients' rights for reimbursement in cross-border health care and has an important impact on the mobility of medical tourists. Four Slovak spa facilities hold the international European quality certificate EuropeSpa med. This certification is of particular importance if the spas wish to provide spa care to foreigners to a larger extent.

The state support for accommodation facilities, including spa undertakings, is based on four instruments. (1) Decreasing the value-added tax [70] on accommodation services from $20 \%$ to $10 \%$ as of 1 January 2019. (2) At the same time, as of 1 January 2019, an entity employing more than 49 employees is obliged to provide a recreation allowance. Employees, whose employment relationship with the employer lasts for at least 24 consecutive months, may apply for a recreation allowance from the employer. The employer is obliged to pay the employee a recreation allowance in the amount of $55 \%$ of the recreation expenses, but not more than $€ 275$ per calendar year. Eligible recreation expenses are expenses demonstrably incurred by the employee on tourism services related to accommodation for at least two nights in the Slovak Republic. The employer is obliged to contribute not only to the recreation of the employee, but also to the recreation of the spouse and the child of the employee and other persons living in a common household with the employee, provided that they are on holiday together with the employee. From the employee's point of view, recreation allowances provided to the employee by his/her employer are exempt from income tax, while the employee and employer do not pay any health and social insurance contributions on such allowances. For employers (including natural 
persons with income from business and other self-employment activities), recreation allowances are a tax-deductible expense according to Act No. 595/2003 Coll. on Income Tax, which reduces their income tax base. This support could increase the percentage of short-term wellness stays in the following years. (3) Demonstrably paid reimbursements related to spa care incurred in natural medical spas shall, from 1 January 2018, be deemed a non-taxable part of a natural person's tax base. The non-taxable part of the tax base for spa care may include payments for spa treatments provided, including payments for meals and accommodation made by the taxpayer and which are not paid to the natural person from other sources, e.g., paid out of public health insurance or by the employer as a recreation allowance, while the duration of the stay in the spa is not decisive. The non-taxable part of the tax base for spa care may be applied by a natural person as evidenced by proof of payment, but cannot be more than $€ 50$ per year for each person for whom the non-taxable part of the tax base is applied (spouse and child). (4) At the same time, more favorable tax treatment is given to reconstruction and modernization works on buildings which are located in the spa area, are used for spa care, and are part of a natural medical spa. From a tax perspective, they are treated as other assets that are depreciated separately from the building (which are currently depreciated over a period of 40 years) and are included in the depreciation group with a depreciation period of 6 years.

The limiting factor of this study is the fact that it does not take into account the impact of governmental instruments furthering domestic and spa tourism. The assessment of medically recognized services submitted by natural medical spas for settlement (and checked in the health insurance information system) may result in more accurate results. At the same time, further research should focus on the cost-benefit analysis of the costs of additional pharmacological treatment and reimbursements to physiotherapeutic rehabilitation clinics and departments in the event that spa treatment expenditure is reduced by health insurance companies. As such, further research is still required in this field.

\section{Conclusions}

Financial resources for spa treatment coming from public health insurance generally showed a growing trend in years 2006-2018. Nonetheless, the share of expenditure on spa treatment out of general expenditure on health services, after an increase between the years 2006-2011, did not show any clear trend in the following years, appearing in a scale between 1 and $1.39 \%$ in the second part of the investigated period. Public health insurance appears to be the dominant source of income for spa companies operating in Slovakia, having the biggest influence on its revenues. Self-paying patients in turn seem to be more profitable for spa companies. A decreasing role of foreign patients in generating income for spa companies appears in the investigated period. The possibility of attracting foreign visitors seems not to be taken advantage of by the companies in a scale adequate to its potential. Revenues of spa companies in Slovakia show the highest correlation with domestic visitors' medical stays paid by health insurance, as well as with general health expenditures of health insurance companies and GDP of the Slovak Republic. The revenues therefore reflect the general condition of the Slovak economy and its influence on health care financing rather than any changes in policy of insurance companies regarding spa treatment. The level of financing spa treatment by health insurance is being perceived as being too low, which is confirmed by visibly weak correlations between spa companies' after-tax profits and medical stays covered by health insurance, as well as general spending of health insurance funds on spa treatment.

Author Contributions: Conceptualization, J.D. and P.R.; Methodology, J.D. and P.R.; Software, P.R.; Validation, J.D. and P.R.; Formal Analysis, P.R.; Investigation, J.D. and P.R.; Resources, J.D. and P.R.; Data Curation, J.D. and P.R.; Writing-Original Draft Preparation, J.D., P.R. and M.C.; Writing-Review and Editing, J.D. and P.R.; Visualization, J.D. and P.R.; Supervision, J.D. and P.R.; Project Administration, M.C.; Funding Acquisition, M.C. All authors have read and agreed to the published version of the manuscript.

Funding: The article was publishing as a part and with financial support of the Scientific Grant Agency of the Ministry of Education, Science, Research and Sport of the Slovak Republic and the Slovak Academy of Sciences No. VEGA 1/0515/18 "The decision-making model of process of evaluating raw material policy of regions". 
Conflicts of Interest: The authors declare no conflict of interest. The funders had no role in the design of the study; in the collection, analyses, or interpretation of data; in the writing of the manuscript, or in the decision to publish the results.

\section{References}

1. Kasagranda, A.; Gurňák, D. Spa and Wellness Tourism in Slovakia (A Geographical Analysis). Czech J. Tour. 2017, 6, 27-53. [CrossRef]

2. Fialová, D.; Orosz, Ö. Vývoj lázeňství na území dnešního Slovenska (v období od konce 16. století do současnosti) [Development of spa industry in the territory of present-day Slovakia (from the end of the 16th century to the present)]. Klaudyán: Internetový Časopis Pro Hist. Geogr. A Enviromentální Dějiny 2012, 8-9, 94-106.

3. Kraftová, I.; Masuyama, Y.; Matěja, Z.; Kornfeldová, M. Společenská odpovědnost v lázeňství: Shody čí rozdíly? (Komparativní studie čéskeho a Japonského prostředí) [Corporate social responsibility in spa industry: Equalities or differences? (comparative study of Czech and Japanese environment)]. E+M Ekon. A Manag. 2011, 14, 123-136.

4. Mulík, J. Dejiny kúpel'ov a kúpel'níctva na Slovensku [History of spas and spa industry in Slovakia], 1st ed.; Osveta: Martin, Czechoslovakia, 1981; p. 187.

5. Eliašová, D. Slovenské kúpel'níctvo v 20. Storočí [Slovak spas in the 20th century], 1st ed.; Ekonóm: Bratislava, Slovakia, 2009; p. 201.

6. Kmeco, L'. Development of the Spa Industry and Its Legislation in Slovakia since 1989. Studia Tur. 2019, 10, 37-49.

7. Williams, A.M.; Baláž, V. Privatisation and the development of tourism in the Czech Republic and Slovakia: property rights, firm performance, and recombinant property. Environ. Plan. A 2000, 32, 715-734. [CrossRef]

8. Nemec, J.; Lawson, C. Health policy in Slovakia and the outcomes of health care reforms: 1989-2003. J. Comp. Policy Anal. Res. Pract. 2005, 7, 49-71. [CrossRef]

9. Derco, J. The Slovak spas in the light of the health care system. Tour. Plan. Dev. 2014, 11, 243-252. [CrossRef]

10. Derco, J.; Pavlisinova, D. Financial position of medical spas-the case of Slovakia. Tour. Econ. 2017, 23, 867-873. [CrossRef]

11. Derco, J. Impact of health care funding on financial position of Slovak medical spas. Turiz. Medunarodni Znan. Stručni Časopis 2017, 65, 376-380.

12. Holub, D.; Magurová, H.; Kropaj, M. Legislation of spa industry as a part of tourism in the Slovak Republic. In Právo v Podnikání Vybraných Členských Států Evropské Unie, 1st ed.; Štěpánková, K., Ed.; TROAS Ltd.: Prague, Czech Republic, 2017; Volume 9, pp. 78-84.

13. Kerekeš, J. Kúpel'níctvo a jeho Význam v Turizme [Spa industry and its importance in tourism], 1st ed.; Weltprint Ltd.: Bratislava, Slovakia, 2018; p. 285.

14. Kotikova, H.; Schwartzhoffova, E. Health and spa tourism in the Czech and Slovak Republics. In Medical tourism: The Ethics, Regulation, and Marketing of Health Mobility, 1st ed.; Hall, C.M., Ed.; Routledge: Abingdon, UK, 2013; pp. 109-122. [CrossRef]

15. Marčeková, R.; Pompurová, K.; Gúčik, M. Zdravotný Cestovný Ruch [Health tourism], 1st ed.; Belianum Matej Bel University Press: Banská Bystrica, Slovakia, 2015; p. 168.

16. Vystoupil, J.; Šauer, M.; Bobková, M. Spa, Spa Tourism and Wellness Tourism in the Czech Republic. Czech J. Tour. 2017, 6, 5-26. [CrossRef]

17. Dryglas, D.; Różycki, P. Profile of tourists visiting European spa resorts: a case study of Poland. J. Policy Res. Tour. Leis. Events 2017, 9, 298-317. [CrossRef]

18. Dryglas, D.; Salamaga, M. Segmentation by push motives in health tourism destinations: A case study of Polish spa resorts. J. Destin. Mark. Manag. 2018, 9, 234-246. [CrossRef]

19. Dryglas, D.; Salamaga, M. Applying destination attribute segmentation to health tourists: A case study of Polish spa resorts. J. Travel Tour. Mark. 2017, 34, 503-514. [CrossRef]

20. Kapczyński, A.; Szromek, A.R. Hypotheses concerning the development of polish spas in the years 1949-2006. Tour. Manag. 2008, 29, 1035-1037. [CrossRef]

21. Szromek, A.R.; Wybrańczyk, K. Proposal of Value for Customer of Spas: Expectations of Spa Patients and Tourist in Polish Spas. Sustainability 2019, 11, 3598. [CrossRef]

22. Szromek, A.R.; Naramski, M. A Business Model in Spa Tourism Enterprises: Case Study from Poland. Sustainability 2019, 11, 2880. [CrossRef] 
23. Szromek, A.R.; Romaniuk, P.; Hadzik, A. The privatization of spa companies in Poland - an evaluation of policy assumptions and implementation. Health Policy 2016, 120, 362-368. [CrossRef]

24. Smith, M.; Puczkó, L. Taking your life into your own hands? New trends in European health tourism. Tour. Recreat. Res. 2010, 35, 161-172. [CrossRef]

25. Gustavo, N.S. A 21st-century approach to health tourism spas: The case of Portugal. J. Hosp. Tour. Manag. 2010, 17, 127-135. [CrossRef]

26. Vilar Rodriguez, M.; Lindoso Tato, E. From the belle epoque to the new era of spa tourism: spas in Spain in historical perspective (1874-2016). AYER 2019, 114, 23-64.

27. Smith, M. Baltic health tourism: Uniqueness and commonalities. Scand. J. Hosp. Tour. 2015, 15, 357-379. [CrossRef]

28. Matlovičová, K.; Šimčík, D. Spa and Wellness Tourism in Estonia. Geogr. Cassoviensis 2010, 4, 108-113.

29. Snoj, B.; Mumel, D. The measurement of perceived differences in service quality-The case of health spas in Slovenia. J. Vacat. Mark. 2002, 8, 362-379. [CrossRef]

30. Nikoli, G.; Lazakidou, A. A review of thermal tourism in Europe and Greece. Turiz. Međunarodni Znan. Stručni Časopis 2019, 67, 318-322.

31. Vrkljan, S.; Hendija, Z. Business performance of health tourism service providers in the Republic of Croatia. Acta Clin. Croat. 2016, 55, 79-85. [CrossRef] [PubMed]

32. Trnka, S. Efficacious holidays: The therapeutic dimensions of pleasure and discipline in Czech respiratory spas. Med Anthropol. Q. 2018, 32, 42-58. [CrossRef]

33. Pforr, C.; Locher, C. The German spa and health resort industry in the light of health care system reforms. J. Travel Tour. Mark. 2012, 29, 298-312. [CrossRef]

34. Hofer, S.; Honegger, F.; Hubeli, J. Health tourism: definition focused on the Swiss market and conceptualisation of health(i)ness. J. Health Organ. Manag. 2012, 26, 60-80. [CrossRef]

35. Vavrečková, E.; Stuchlíková, J.; Dluhošová, R. The Results of the Development of Balneal Care Provision and the State of the Czech Spa Industry in Connection with the Changes in Legislation. Czech J. Tour. 2017, 6, 93-104. [CrossRef]

36. Mainil, T.; Eijgelaar, E.; Klijs, J.; Nawijn, J.; Peeters, P. Research for TRAN Committee-Health Tourism in the EU: A General Investigation, 1st ed.; European Parliament, Policy Department for Structural and Cohesion Policies: Brussels, Belgium, 2017; p. 27.

37. Spa Tourism 2018-Accommodation Statistics of Tourism in Slovakia. Available online: https://www.mindop. sk/ministerstvo-1/cestovny-ruch-7/statistika/kupelny-cestovny-ruch (accessed on 5 December 2019).

38. Health Statistics Yearbook of the Slovak Republic 2018. Available online: http://www.nczisk.sk/Statisticke_ vystupy/Zdravotnicka_rocenka/Pages/default.aspx (accessed on 5 December 2019).

39. Health Statistics Yearbook of the Slovak Republic 2017. Available online: http://www.nczisk.sk/Statisticke_ vystupy/Zdravotnicka_rocenka/Pages/Archiv.aspx (accessed on 5 December 2019).

40. Health Statistics Yearbook of the Slovak Republic 2016. Available online: http://www.nczisk.sk/Statisticke_ vystupy/Zdravotnicka_rocenka/Pages/Archiv.aspx (accessed on 5 December 2019).

41. Health Statistics Yearbook of the Slovak Republic 2015. Available online: http://www.nczisk.sk/Statisticke_ vystupy/Zdravotnicka_rocenka/Pages/Archiv.aspx (accessed on 5 December 2019).

42. Health Statistics Yearbook of the Slovak Republic 2014. Available online: http://www.nczisk.sk/Statisticke_ vystupy/Zdravotnicka_rocenka/Pages/Archiv.aspx (accessed on 5 December 2019).

43. Health Statistics Yearbook of the Slovak Republic 2013. Available online: http://www.nczisk.sk/Statisticke_ vystupy/Zdravotnicka_rocenka/Pages/Archiv.aspx (accessed on 5 December 2019).

44. Health Statistics Yearbook of the Slovak Republic 2012. Available online: http://www.nczisk.sk/Statisticke_ vystupy/Zdravotnicka_rocenka/Pages/Archiv.aspx (accessed on 5 December 2019).

45. Health Statistics Yearbook of the Slovak Republic 2011. Available online: http://www.nczisk.sk/Statisticke_ vystupy/Zdravotnicka_rocenka/Pages/Archiv.aspx (accessed on 5 December 2019).

46. Health Statistics Yearbook of the Slovak Republic 2010. Available online: http://www.nczisk.sk/Statisticke_ vystupy/Zdravotnicka_rocenka/Pages/Archiv.aspx (accessed on 5 December 2019).

47. Health Statistics Yearbook of the Slovak Republic 2009. Available online: http://www.nczisk.sk/Statisticke vystupy/Zdravotnicka_rocenka/Pages/Archiv.aspx (accessed on 5 December 2019).

48. Health Statistics Yearbook of the Slovak Republic 2008. Available online: http://www.nczisk.sk/Statisticke vystupy/Zdravotnicka_rocenka/Pages/Archiv.aspx (accessed on 5 December 2019). 
49. Health Statistics Yearbook of the Slovak Republic 2007. Available online: http://www.nczisk.sk/Statisticke_ vystupy/Zdravotnicka_rocenka/Pages/Archiv.aspx (accessed on 5 December 2019).

50. Health Statistics Yearbook of the Slovak Republic 2006. Available online: http://www.nczisk.sk/Statisticke_ vystupy/Zdravotnicka_rocenka/Pages/Archiv.aspx (accessed on 5 December 2019).

51. Health Statistics Yearbook of the Slovak Republic 2005. Available online: http://www.nczisk.sk/Statisticke vystupy/Zdravotnicka_rocenka/Pages/Archiv.aspx (accessed on 5 December 2019).

52. Report on the State of Public Health Insurance for 2018. Available online: http://www.udzs-sk.sk/web/sk/ spravy (accessed on 5 December 2019).

53. Report on the State of Public Health Insurance for 2017. Available online: http://www.udzs-sk.sk/web/sk/ spravy (accessed on 5 December 2019).

54. Report on the State of Public Health Insurance for 2016. Available online: http://www.udzs-sk.sk/web/sk/ spravy (accessed on 5 December 2019).

55. Report on the State of Public Health Insurance for 2015. Available online: http://www.udzs-sk.sk/web/sk/ spravy (accessed on 5 December 2019).

56. Report on the State of Public Health Insurance for 2014. Available online: http://www.udzs-sk.sk/web/sk/ spravy (accessed on 5 December 2019).

57. Report on the State of Public Health Insurance for 2013. Available online: http://www.udzs-sk.sk/web/sk/ spravy (accessed on 5 December 2019).

58. Report on the State of Public Health insurance for 2012. Available online: http://www.udzs-sk.sk/web/sk/ spravy (accessed on 5 December 2019).

59. Report on the State of Public Health Insurance for 2011. Available online: http://www.udzs-sk.sk/web/sk/ spravy (accessed on 5 December 2019).

60. Report on the State of Public Health Insurance for 2010. Available online: http://www.udzs-sk.sk/web/sk/ spravy (accessed on 5 December 2019).

61. Report on the State of Public Health Insurance for 2009. Available online: http://www.udzs-sk.sk/web/sk/ spravy (accessed on 5 December 2019).

62. Report on the State of Public Health Insurance for 2008. Available online: http://www.udzs-sk.sk/web/sk/ spravy (accessed on 5 December 2019).

63. Report on the State of Public Health Insurance for 2007. Available online: http://www.udzs-sk.sk/web/sk/ spravy (accessed on 5 December 2019).

64. Report on the State of Public Health Insurance for 2006. Available online: http://www.udzs-sk.sk/web/sk/ spravy (accessed on 5 December 2019).

65. Report on the State of Public Health Insurance for 2005. Available online: http://www.udzs-sk.sk/web/sk/ spravy (accessed on 5 December 2019).

66. Spa Care in the Slovak Republic in 2018. Available online: http://www.nczisk.sk/statisticke_vystupy/ tematicke_statisticke_vystupy/Kupelna_starostlivost/Pages/default.aspx (accessed on 5 April 2020).

67. Suchecka, J.; Jaworska, R. Finansowanie Publiczne i Realizacja świadczeń lecznictwa uzdrowiskowego w Polsce w latach 2003-2014 [The Public Financing and Implementation of Health Resort Services in Poland in the years 2003-2013]. Probl. Zarzadzania 2015, 13, 216-230. [CrossRef]

68. Romaniuk, P.; Holecki, T. Finansowanie świadczeń uzdrowiskowych w Polsce [Financing of spa services in Poland]. In Rola Uzdrowisk i Przedsiębiorstw Uzdrowiskowych w Turystyce i Lecznictwie Uzdrowiskowym, 1st ed.; Szromek, A.R., Ed.; Proksenia: Kraków, Poland, 2014; pp. 177-192.

69. Szromek, A.R.; Romaniuk, P. Ubezpieczenie uzdrowiskowe kuracjuszy-Trzy propozycje rozwiązań systemowych $\mathrm{w}$ ramach ubezpieczenia zdrowotnego [Spa insurance for patients-Three proposals for system solutions as part of health insurance]. In Uzdrowiska i ich funkcja turystyczno-lecznicza, 1st ed.; Szromek, A.R., Ed.; Proksenia: Kraków, Poland, 2012; pp. 275-296.

70. Pavliková, L'.; Bánociová, A.; Jakubíková, E. The Practical Application of Value Added Tax in the Slovak Republic in the Spa Facilities. Procedia Econ. Financ. 2014, 15, 192-199. [CrossRef]

(C) 2020 by the authors. Licensee MDPI, Basel, Switzerland. This article is an open access article distributed under the terms and conditions of the Creative Commons Attribution (CC BY) license (http://creativecommons.org/licenses/by/4.0/). 